\title{
An Invasion of a Different Kind: The U.s. Office of War Information and "The Projection of America" Propaganda in the Netherlands, 1944-1945
}

\author{
Marja Roholl
}

We are telling the rest of the world about the United States not because we want liking and admiration as ends in themselves, but because we realize that in order to work effectively and harmoniously with us in the creation of a lasting peace, other nations must understand us better than they have in the past. ${ }^{1}$

(CIT., HART 2013, 104)

June 6, 1944: D-Day, the start of the invasion of Normandy. Soldiers, tanks and Jeeps rolling out of invasion vessels, parachutists making airborne landings, horrific battles and Allied victories at heavy costs. The images of the Allied invasion on the beaches of Normandy are part of our collective memory, shaped by an abundance of photos, documentaries and (Hollywood) films. Less well-known is the story of the accompanying propaganda invasion (Scott 2006a; Scott 2008; Miller 2014). The vessels and airplanes landing in Normandy brought not only soldiers, military supplies, food and medicines, but also more unlikely "weapons": crates full of magazines, books, and movies, the majority of which were produced by the U.S. Office of War Information Overseas Branch (оW ов) and the British Ministry of Information (MOI), organizations charged with overseas propaganda (Hench $2010,1-2$ ). These media were targeted at civilians rather than enemy soldiers. Their goal was not only to smooth the transition from occupation and war to liberation, but also to shape the post-war peace.

1 I would like to thank Antje Boehmert for generously sharing her research, and Kate Delaney for her assistance with the English text.

(C) MARJA ROHOLL, 2018 | DOI 10.1163/9789004292017_003

This is an open access chapter distributed under the terms of the prevailing CC-BY-NC License at the time of publication. 
Only days after the liberation of the first French city, Cherbourg, on the 4th of July, 1944, the Office of War Information and the Ministry of Information showed their films in half-destroyed cinemas with the help of American equipment and personnel. In addition, the mobile film units of the Allied Information Service ${ }^{2}$ (AIS) showed films in schoolhouses and comparable venues. A full mix of information and entertainment was at hand, with a program composed of owI and MOI newsreels and documentaries, and a Hollywood comedy (Bishop 1966, 267-68; Miller 2014). Two days later, a one-ton truckload of magazines and books arrived in Cherbourg, the contents quickly finding their way into bookstores and Allies' reading rooms (Hench 153). These first shipments of films, magazines and books were soon to be supplemented by a large-scale multi-media program, not only in France, but also in other countries such as the Netherlands. Even though it was a joint British-American endeavor in the sense that both information agencies worked together on war-related materials, there was significant competition between the partners as well. Each side produced propaganda with an emphasis on its own society, its own contributions to the war, and the role it aspired to in the postwar world. Compared to the American program, the British one was modest, reflecting the differences in power positions and availability of means (Bennett 316$).{ }^{3}$ The focus of this essay is on the American program.

Thus, important as winning the war may have been, consolidating the peace on American terms was also imperative. The United States would not succumb to the political contractions that followed the First World War: this time the American government worked towards a new world order which the United States would dominate; and the Office of War Overseas Branch had a role to play in making this a reality.

The propaganda campaigns for overseas, labeled "the Projection of America" in 1943, involved multiple media, and ranged in specificity from one-size-fitsall to nationally and even regionally specific endeavors (Hart 2013, 71-107). The campaigns targeted various audiences with a carefully selected range of media, themes and arguments. The emphasis here will be on those parts of "the Projection of America" campaign developed for a general public, showing

2 The Allied Information Service (AIS) was the friendlier term used in non-enemy countries in Europe for the Psychological Warfare Division (PWD) of the Supreme Headquarters Allied Expeditionary Force (SHAEF).

3 The Soviet Union had its own program ready for the countries it liberated, and for the ones defeated by Allied efforts, such as Germany and Italy. The United States would try to keep Russian materials out of Italy. 
"how America lives" with less attention for programs directed at the elites. While books were often directed towards elites, magazines and films stand out as media of choice for a general public. This essay describes these propaganda operations housed in the owI's Bureau of Overseas Publications and the Overseas Bureau of Motion Pictures, with illustrations from one particular setting: the Netherlands, $1944-45{ }^{4}$

Before taking a look at the owi Overseas Branch program in the Netherlands, a description of the organization and its goals is in order.

\section{The U.s. Office of War Information}

Japan's attack on Pearl Harbor on December 7, 1941, led to America's total involvement in the war, including on the propaganda front. In June 1942, President Roosevelt folded a number of existing organizations charged with propaganda and information activities at home and overseas into the newly created U.s. Office of War Information. The Office of War Information (owI) consisted of two branches, the Domestic Branch and the Overseas Branch. The director's office and most of the Domestic Branch were located in Washington, while the communication and news center, together with the offices of the Overseas Branch, were mainly located in New York; the Overseas Branch also had offices in Hollywood and outposts around the globe (Winkler 1978; Bishop 1966).

Elmer Davis was appointed director of the OwI. He was a highly respected journalist for The New York Times, and radio commentator and anchor for CBS. Democrats and Republicans alike considered him the right man for the job: a non-partisan, trusted and trustworthy voice. In contrast, many of the people employed by the owI and its predecessors demonstrated a distinctly left-ofcenter, liberal orientation in their work and politics, and were often supporters of President Roosevelt and the New Deal. For instance, Robert Sherwood, one of President Roosevelt's confidants and speechwriters, was appointed director of the Overseas Branch. ${ }^{5}$ Republicans and conservative Democrats alike feared owi Domestic Branch's potential propaganda power in the hands of the Roosevelt administration on a national platform, and criticized owI's concern

4 For a sense of how this played out in other nations, see for instance David W. Ellwood. 2010. The Shock of America. Europe and the Challenge of the Century, chapter 7. Oxford: Oxford University Press.

5 By contrast, the Office of Strategic Services (oss), with William Donovan at the helm, in charge of "black propaganda" abroad, was seen as a stronghold of the Republicans. 
about the position of African Americans (Hart 2013, 91-103). As a result, the Domestic Branch lost most of its funding in the summer of 1943. There was no concern, however, about propaganda directed at other countries' inhabitants, whether enemies or allies. Moreover, the Overseas Branch could quote high-ranking members of the military regarding the usefulness of its programs "over-there." Differences of opinion about strategy, about the relationship between foreign policy and propaganda, and personal rivalries, however, led to some shifts in personnel in the summer of 1943. Edward Barrett, deputy director, replaced Robert Sherwood as director of the us-based Overseas Branch; Sherwood in turn became the new head of the most important outpost, in London.

From the spring of 1944 onwards, the Overseas Branch's work was increasingly done by the outposts. Sherwood was charged with the planning of "the Projection of America" propaganda initiative around the invasion of Normandy and during the subsequent transition to peace. The London Outpost, close to the actual theater of war, and home to many governments in exile including the Dutch, was thus in a good position to adjust propaganda to local needs and to secure propaganda clearances. After the liberation of Paris and Brussels, new outposts there provided additional services for the Netherlands.

\section{"The Projection of America" Guidelines}

The owi Overseas Branch worked with short- and long-term goals and guidelines. During the liberation and consolidation phase, the short-term goals included preventing friction between American/Allied troops and the population of liberated countries. The long-term agenda aimed beyond the war. The owI realized that - not withstanding enormous gratitude for the crucial role the us had played in the liberation - the more important America's position would become, the more concern it would provoke in allied and neutral nations that feared, on the one hand, an American retreat into isolationism (as occurred after the First World War) and, perhaps paradoxically, American hegemony and imperialism on the other (Hart 2013, 104-5; O.W.I. Overseas Branch Guidelines). Moreover, the owI feared that America's new role as world power might be hindered by "misunderstandings" dating back to the pre-war era; a lack of accurate knowledge, Hollywood-generated stereotypes, and last but not least, years of enemy propaganda. The owI's "repair work" was thus to be significant, from addressing prejudices that Americans were rich and culturally backward, to concerns regarding the discrimination 
against African Americans which would undermine America's claim to moral leadership, to distrust about America's postwar agenda (Cousins 1944; Wilson 1944, 2).

The discussions within the owI Overseas Branch about "the Projection of America" guidelines suggest an ingenious and careful response:

Nothing is to be gained by a frontal attack on unfriendly — (and in our view unfair) - sentiments of this kind. They don't deserve to be called opinions, for they have not been reached by rational thought or conscientious deliberation. Rather they are impressions, prejudices, rationalizations and unwarranted deductions. Direct argument may only crystallize or confirm them. (Cousins 14)

Providing alternative narratives was seen as a more fruitful approach, and publications and films were considered the most effective means. The next sections will situate the work of the Bureau of Overseas Publications and the Overseas Bureau of Motion Pictures (омBP), the two organizations charged with implementing "the Projection of America" campaign, before delving more deeply into the Dutch situation.

\section{Overseas Bureau of Motion Pictures (овMP)}

Even though the owI considered movies a crucial medium in the propaganda war, their involvement at the central policy level was minimal. The Bureau of Motion Pictures (BMP) and its overseas division were even referred to as "the stepchildren" of the owI (Bishop 92). Robert Riskin was in charge of the overseas activities. Before the war, he had been a very successful Hollywood screenwriter, most notably known for his collaborations with director Frank Capra on movies such as It Happened One Night, Mr. Deeds Goes to Town, You Can't Take It With You and Meet John Doe. Politically a left-liberal and a Roosevelt supporter, Riskin had been concerned about developments in Germany since Hitler's rise to power and was an early proponent of American intervention, like many others in Hollywood. His Jewish background may have contributed to this awareness (Scott 2006b; Scott 2008).

The овмг had several tools at its disposal: producing newsreels and documentaries, "guiding" Hollywood in its production, and selecting for export Hollywood movies and documentaries made by other government agencies. 


\section{Documentaries}

Of the documentaries selected for screening overseas, the most important was the famous seven-part series Why We Fight, made under the guidance of Frank Capra for the Department of War as instruction films for the American military. ${ }^{6}$ Riskin gave this series priority for overseas exhibition over the owI's own documentary series, The American Scene (Scott 2008). (Both series would appear on Dutch screens in liberated areas, starting in the fall/winter 1944).

The Why We Fight and The American Scene documentaries functioned in complementary ways. The Why We Fight series provided postwar overseas audiences with an overview of the events leading to the Second World War; of "the ugly face" of the enemy often based on the latter's own footage; and of the role played by Allied forces in some of the most important battles. The Why We Fight documentaries retrospectively arranged the past according to an American agenda and set a course for the future, and in so doing earned their value as an owI overseas tool (Doherty 1993).

The American Scene series, produced between 1943 and 1945, can be considered Riskin's signature production. He was convinced that high-quality, subtle documentaries about America would provide an effective means of propaganda overseas. Where the Why We Fight films present emotional, newsreeltype history lessons (Barnouw 158) and the magazines and newsreels traded in more traditional "factual" propaganda, The American Scene documentaries are artistic, engaging and nuanced, armed with a sense of humor and showing the hand of their respective directors, cameramen, and composers. Even though as a Hollywood screenwriter Riskin did not have much experience with making documentaries himself, he was able to attract a stellar group of film and documentary directors to the овмР, for instance Irving Lerner, Arthur Arent, Willard van Dyke, Alexander Hammid, and Joseph von Sternberg as well as leading composers like Aaron Copland and Virgil Thomson (Scott 2006 a/ b and 2008; Miller 2014).

6 The seven parts were: Prelude to War (1942); The Nazi Strike (1943); Divide and Conquer (1943); The Battle of Britain (1943); The Battle of Russia (1943); The Battle of China (1944) and War Comes to America (1945). Much has been written over the years on Capra's Why We Fight series; Ian Scott's work and the documentary Projections of America brought Riskin's work out of Capra's shadow and into the light, a much-deserved outcome.... The official title at the time was the American Scene. A Series, also sometimes referred to as the Projection of America Series. Shown in the Netherlands at the time under the series title Amerika in Beeld. Scott and Miller refer to it as Projections of America. 
The American Scene series set out to tell the world what it would be like to live in America, what ideals make America what it is-something not yet done in the interwar years - and yes, it presented that American scene through a liberal, yet due to owi policies, restricted, prism (MacCann 147). Produced from the start with an overseas audience in mind, The American Scene documentaries were in conversation with their audiences overseas, "playing" with their fascinations and prejudices and addressing their lack of knowledge and understanding. They did not focus on America's war industry and military might — people knew enough about that through other owi products and often their own experience on the ground. They sought to counteract the impression of America as a country of "gangsters and cattle-rustling cowboys," showing instead that it was composed of hardworking immigrants who found a good new home (NYT, March 7, 1943); they provided insights into the workings of American democratic, economic and educational systems, with an emphasis on small-town values, together leading to the successful and attractive "American Way of Life." They also underlined America's dedication, as the new world leader, to international forums to secure peace once the hostilities were over.

The Why We Fight and The American Scene series were both government productions. Yet, the government was also greatly interested in bringing the commercial Hollywood productions in line with the owr's overseas goals.

\section{Hollywood and Public Opinion Overseas}

In the context of its propaganda efforts the owI underlined "the value of the screen as an international builder of public opinion" (Segrave 131-33; Koppes and Black 87-105). Therefore, Riskin's team was very much involved with "guiding" Hollywood in its film production, and was responsible for selecting films for export. Hollywood knew how to make motion pictures, but did not always understand their overseas impact, according to owI director Davis (Hart 2013, 85). The owI considered many Hollywood films, which often emphasized city vices, the Wild West, luxury and romance, a major source of distortion for overseas audiences. Therefore, Riskin urged Hollywood to advance "American global interests by benevolently portraying the nation, its people, institutions, ideals and way of life" (Bennett 2001, $300)$ and to produce "win-the-peace-films." The ow had veto rights over export licenses, and since the overseas market was of great importance for the Hollywood studios, Riskin's “suggestions" resonated with the industry. 
The owI and the military leaders considered Hollywood entertainment movies very important for creating "normalcy" in liberated areas and for generating good will. Hollywood allowed Riskin to handpick "from the shelves" forty movies which he considered to be in accordance with the owI agenda and local sensitivities. These were to be shown in that crucial first phase after liberation, as soon as American/Allied troops had taken over a town or a city. (The MOI was permitted to select thirty movies produced by the British movie industry). The owi/овмp had at the same time a clear eye for Hollywood's needs as well, and the very close personal ties between the Overseas Branch and Hollywood reflect that; Riskin himself is just one example. The owI acknowledged the high commercial value of movies and pledged to help the movie industry reclaim its rights, and secure and expand its markets after the war was over (Bennett 2001). Production in the United States had continued during the war, and the backlogged output was waiting to be released abroad, with more in the making.

The Dutch case study will provide insights into the film activities of the Overseas Branch in a local context, but first we need to look at the organization responsible for publications.

\section{Bureau of Overseas Publications}

The Bureau of Overseas Publications was the Overseas Branch's most elaborate endeavor. Part of it was specifically directed towards elites, demonstrating that "America does not only fight or work or eat or amuse itself, but America "thinks" (Allen 1945). Books and "serious" magazines were considered the main carriers for that message. Illustrated periodicals and booklets catering to a general public, however, formed the core of the publication program (Roholl 2012). And here we see the hand of the directors of the Overseas Branch most clearly. Robert Sherwood had an interest in photo-essays-we see this reflected in owI-publications such as Look and Victory. Edward Barrett had worked for Newsweek, had an interest in sociology, and favored a more impersonal socialsciences approach, as reflected in the illustrated booklet American Women. ${ }^{7}$ The magazines were repeatedly discussed and reviewed at the central level in Washington, at the Overseas Branch's offices in New York, and at the outposts overseas. Products catering to audiences in several countries—one size fits

7 These would be distributed in the Netherlands in Dutch, under the titles KIJK, Victory and De Amerikaansche Vrouw 
all-were produced in New York; by definition these were not able to address current or local developments. Products that targeted specific countries would increasingly be produced at the major outposts, as will be demonstrated in the following Dutch case study.

\section{"The Projection of America" in a Dutch Context}

Our projection of America must vary with the differing interests, intellects, economics, politics and cultures of our main target areas (Wilson $1944,4)$.

The liberation of the Netherlands took longer than anticipated. On September 12, 1944, American troops liberated the small village of Mesch; the city of Maastricht followed a couple of days later. It would take until May 1945 , however, before the whole country was liberated, due to strategic considerations and the failure of Operation Market Garden-memorialized in the Hollywood film A Bridge Too Far (1977). While American forces liberated the first towns and cities, the Canadian and British forces played a more crucial role in liberating the rest of the country; the Polish troops contributed significantly as well. Not until June 1945 was the Dutch government fully reinstalled in The Hague (Klinkert 2009). In this long interregnum, in accordance with the Civil Affairs agreement signed by the Dutch government in May 1944, the commander of the Allied Forces exercised full authority, while working closely together with the Dutch Military Authority (Schoonoord 2010). This situation provided the OWI-and the MOI-unique opportunities to carry out their agendas. And even though American forces were not involved in the liberation of all parts of the Netherlands, the owi's propaganda products would become available in the country at large, thanks to the Allied Information Service.

The propaganda program for the Netherlands was based on the general outlines of the owi Overseas Branch, combined with specifics for the local situation. The well-known American anthropologist Ruth Benedict and her colleagues working for the owi during the war had assessed the Dutch, using secondary literature and interviews with Dutch immigrants because of the limitations imposed by the war. The Dutch, Benedict concluded, shared the general "misunderstandings" of, and fascination with, America. Yet, the owI also identified additional specific circumstances and traits. All reports mentioned that the Dutch had "intellectual fibre:" they were very well educated and accustomed to high journalistic and cinematic standards, so that only 
high-quality products would suffice. In Italy, by contrast, the owI adapted its program to match the high illiteracy rates, relying heavily on visuals.

The ow singled out the Netherlands-along with Spain, Italy, and Portugal—for its conservative attitude towards women. The Overseas Branch feared Dutch criticism of American family life and the role of 'modern' American women therein, and of society at large as a consequence. Indeed, for instance during the interwar years, the Katholieke Illustratie (Catholic Illustrated) had presented American women as selfish mothers and wives; too much enthralled with themselves, they spent the free time they gained with the labor-saving kitchen gadgets on themselves instead of on the family (Roholl 1994). The Dutch were also described as a proud people, who were trying to cope with their diminished role in the world and their dependency on the help of the Allies, in Europe and Asia alikesomething that could easily turn into resentment. This attitude went hand in hand with reservations over America's postwar role as world leader, and fears over American territorial ambitions and desire for economic concessions in the Dutch East Indies and elsewhere.

It was the Overseas Branch's challenge to "translate" these points into "the Projection of America" programs for the Netherlands during the liberation and consolidation phase.

\section{Liberation and "the Projection of America"}

The military and the owI anticipated that, in addition to deep-felt gratitude and admiration, frictions might arise between American soldiers and Dutch civilians. They realized that American soldiers served a double function as liberating warriors and as front-line ambassadors. They were the first real Americans people would meet, so the first impression was important. The soldier was seen by owi as "our best chance to facilitate and promote a sympathetic and appreciative judgment of Americans in general" (Van Schreven 1). Thus, American soldiers were provided with information, and lists with "Do's and Don'ts," based in part on Benedict's anthropological reports. Benedict described Dutch culture as very home-oriented and hospitable, and she explained different patterns and codes in dating. These good-looking "doughboys," from all regions of America and from all walks of life, bringing with them goodies such as cigarettes, chewing gum, chocolate, canned food, and products of America's popular culture, were in a sense "walking bill boards" for the American way of life, "ambassadors for a society of abundance," embodying the promises of an American-led future (Ellwood 2012B; Schrijvers 2012). Yet, 
the many interactions of women with American (and Canadian) soldiers also created resentments among Dutch men about "unfair competition," something which Benedict had predicted as well. Still, gratitude and curiosity won handily in the period under consideration.

The owi Overseas Branch aimed to "contextualize" the American soldiers "invading" the Netherlands with publications such as Schetsen uit het Amerikaansche Familieleven (Sketches of American Family Life), based on the Ladies' Home Journal series "How America Lives." The ow I wanted to show that what these soldiers called home was different from the image most Dutch people had. Through eighteen personal stories it showed that American families were very much affected by the war, according to the owI, a fact greatly underappreciated by the Dutch; the stories gave a face to these young American soldiers and the families they left behind. African American families were absent. America was presented as a country of immigrants, among them Dutch-a recurrent theme in owI's propaganda. Emphasis was placed on small-town America which provided a contrast with the city life and its vices, which the Dutch were more fascinated by and familiar with through pre-war illustrated magazines and Hollywood films. Schetsen also emphasized the central role women played in the American family and the community at large, a topic that would later take center stage in the booklet De Amerikaansche Vrouw.

\section{Magazines}

Magazines in the aggregate illustrated the transition from war and liberation, to peace and consolidation, under American aegis. They all relied heavily on very professionally produced photo-essays as their mode of communication, combining the "factuality" of the word with the expressivity and emotion of the visuals. The core magazine $K I J K^{8}$ entered the country in the soldiers' wake, close to the battle-line in South Limburg, underscoring the importance attached to propaganda for civilians. It was a thirty-two-page illustrated periodical, produced fortnightly at the London Outpost from September 1944 until December 1945, so beyond the liberation of the whole country and the installation of the Dutch government. It was very popular from the start. The print-run was substantial, around a hundred thousand, yet too low to satisfy the public's demand, particularly after large parts of the country had been liberated. One should also note that it would take a while before the Dutch press

8 English title Look. The British equivalent was Big Ben, of which just nine issues were published. 
and publishers began to function properly, providing an additional explanation for the popularity of American - and British — propaganda material.

KIJK served two separate but complementary goals: first, in the short run, to inform the Dutch about current developments specifically in the war in Europe and the Pacific (Dutch East Indies), functioning as a "newsreel" of sorts. The emphasis was on the military role the us played, but the magazine also gave huge credit to the other Allies, especially the new Ally, the Soviet Union. Dutch contributions were also more than generously acknowledged - part of a strategy of cementing good relationships with the Dutch population. Second, there was the familiar long-term agenda: "educating" the population about America: the importance of the Four Freedoms, the educational system, authentic American culture, and much more. The owi Overseas Branch would have preferred to also address the discrimination against African Americans in a "constructive way," but there was a ban on taking up such issues at the highest level (Hart 2013, 91-95). In the Netherlands, the position of African Americans was not much of an issue at the time, even though German propaganda had tried to capitalize on it. In other parts of the world the issue played out differently, undermining America's moral position as prospective leader of the free world.

$K I J K$ also connected the war with the postwar period. The economic system that produced the "Arsenal of Democracy" - the mass-produced tanks, ships, airplanes and more - that enabled America to defend democracy at home and abroad, would be converted into "the democracy of consumption" at home, but also abroad. And here, other ow magazines such as Victory and to a lesser extent De Amerikaansche Vrouw best embody this transition to the postwar period. Victory, although produced and paid for by the owI, was presented to the Dutch as a commercially produced magazine, with advertisements for American consumer goods, many targeting women. The ow I was thus helping American business to secure and expand its markets, even though it would take years before the Dutch could afford these products. The importance of $D e$ Amerikaansche Vrouw is that it showed that a desirable and commodity-rich American lifestyle would not undermine the "natural order." Quite the contrary; it would enable women to spend more "quality time," as wives and mothers, with their families (See also Rosenberg 1999).

Thus, illustrated magazines were cherished propaganda instruments: popular with the public and more easily adaptable to local circumstances than books or movies. But they also posed "challenges," of which the transport of this bulk product proved significant. Moreover, magazines were consumed individually, at home or in a library room, allowing personal choices regarding what to read, and in which order. The situation with the movies differed in many ways. 


\section{Control over the Screen}

For the owI Overseas Branch, movies offered a huge advantage over books and magazines: "little transport was required. A jeep-load of film tins represented weeks of entertainment and information for many cities" (PWD/ SHAEF 1951, 59-6o). Moreover, they functioned differently: moving images, with accompanying music and watched collectively in a dark cinema, added extra layers of communication and persuasion. Movies, more than any other part of "the Projection of America" campaign, show how well positioned the OWI - and the MoI for that matter-was in providing its own materials to Dutch audiences.

Even though the Dutch government and film industry during the war had both, in different ways, envisioned strong roles for themselves in the postwar period, both parties were overrun, failing to protect the small Dutch film industry and prevent "Americanization" of the screen. Thanks to SHAEF, the OWI/ AIs gained total control over the import, rental and distribution of movies, and thus over what was to be shown on the screens in the Netherlands. De Haan even describes this as "a militarized rental system," with considerable profits later handed over to private companies. In addition, American military personnel helped American movie rental firms to retrieve their film properties and secure their film rights (De Haan 62-4).

Cinemas re-opened their doors to the public as soon as the owners and personnel had been screened for their role during the war and all films and stock had been confiscated. Many cinemas had been damaged during the hostilities, and the Allies, especially the Americans, provided crews and material, and even mobile units to accommodate the enormous appetite for movies. People lined up to get in, and tickets were even sold on the black market. In addition to a shortage of working cinemas, there was a shortfall of films, especially after the Northern and Western parts of the country had been liberated as well. As a result, some cinemas in the provinces of Brabant, Limburg and Zeeland had to close again, a situation that met with understandable criticism. Since only American and British films provided by the OWI and MOI were to be shown, American, British, French, Russian and Dutch feature films, lying on the shelves in the Netherlands and approved before the war by the Dutch censor, were not made available. Moreover, it would take until November 1945 before other Allies such as France and the Soviet Union were able to get their movies from outside the country into Dutch cinemas. Even though SHAEF would be dismantled in July 1945, the civilian organization ow continued its involve-

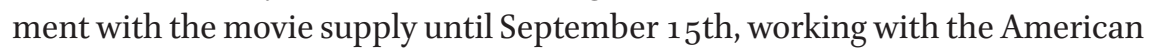
Embassy in The Hague (De Haan 65). 


\section{Hollywood Films}

Of all films, the Hollywood feature films selected by Riskin and his team were most eagerly awaited by audiences. He had chosen some pure and "proper" entertainment films, such as the musical romantic comedy You Were Never Lovelier, Charlie Chaplin's Gold Rush, and Disney's cartoons, "as good will ambassadors and to help alleviate frayed nerves" (NYT, October 31, 1943). In addition, the Overseas Bureau of Motion Pictures hoped "to spread the true facts about America through the motion picture" (Cit. MacCann 140). Selected films included Abe Lincoln in Illinois, detailing his life, politics and election to the presidency, and Young Tom Edison, whose story embodied the American Dream, the rise from rags to riches. It also underscored America as the land of technological inventions, a topic also addressed by KIJK, which published stories on DDT and penicillin, prefab carriers and homes. OwI's affinity with the ideals of the small town and its honest and ordinary people, presented as the heart of America's democracy, is reflected in Mr. Deeds Goes to Town, one of Capra and Riskin's 193os productions, as well as in The Human Comedy. A substantial number of titles were war movies and complemented the Why We Fight series, which was also shown on the Dutch screen. In contrast to the latter, these movies were very personalized. The Sullivans, for instance, which depicts the death of all five Sullivan brothers, showed the Dutch the sacrifices American families made during the war, for the liberation of others. Action in the North Atlantic depicts the dangerous, and for some deadly, voyage of American seamen to Murmansk, with badly needed war goods for their Russian ally.

As noted, Riskin selected Capra's Why We Fight series for priority distribution in the Netherlands (Allen 1945). This series was dubbed into Dutch in London by A. den Doolaard, a famous writer and well-known voice in Holland during the war, thanks to his radio programs from London for Radio Oranje. This suggests active involvement by the Dutch community and government in exile. Different episodes of the Why We fight series were frequently on the bill, both in the cinemas and in non-theatrical venues. Interestingly, the most popular was The Battle for Russia. It got excellent reviews across the religious and political spectrum, not least from the Dutch communist daily De Waarheid, ${ }^{9}$ for its cinematographic qualities, but also for the appealing tribute to the Russian army and population in their heroic fight against the Nazi armies in Stalingrad, present-day Volgograd. Together with the war feature films, these

9 De Waarheid translates as: the truth, or Pravda in Russian. 
documentaries left the audience with the impression of a worldwide deployment of the American military, at high personal cost, working together with allies towards peace and a better world. This was an important message for the Dutch, since the American army did not play the major role in the liberation of the Netherlands itself. The huge American military cemetery in Margraten also reminded the Dutch of the many American soldiers who died outside the Dutch borders, on enemy soil, in Germany, in addition to the casualties in the Netherlands.

\section{The American Scene Documentaries}

The Overseas BMP packaged the American Scene documentaries together with Hollywood films. The series covered the full range of general goals and topics identified by the owI Overseas Branch. In March 1945, ten of the sixteen films produced in 1943 and 1944 were dubbed into Dutch by A. den Doolaard, in London. ${ }^{10}$ This subset covered the owI's main themes and messages, with the notable exception of planning for the postwar period through the United Nations (Allen. 1945, 7-8). The documentaries produced in 1945 emphasized this latter issue, but it is not clear whether the films covering this topic were made available in the Netherlands.

While parts of the Why We Fight series frequently appeared on movie bills and were extensively reviewed in the newspapers, the American Scene shorts were conspicuously absent." There were, however, some notable exceptions. Very appropriately the first of this series shown in the Netherlands was The Autobiography of a Jeep. Allied forces had entered the country in Jeeps, and "the new kid around the bloc" made quite an impression. While there were no ads for this short documentary in the newspapers, there were many positive reviews. The reviewers thought highly of having the Jeep narrating its own (hi)story — a friendly and whimsical touch — and stressed the crucial role this mass-produced American invention played in the war. The newspapers also

10 Cowboy; The Autobiography of a Jeep; Swedes in America; Pipeline; The Town; Oswego; A Journey; City Harvest; Toscanini-Hymn of the Nations, and Valley of the Tennessee.

11 I have searched Delpher, a website providing full-text Dutch language digitized newspapers. The difference may be attributable to the running lengths of the respective projects, with Why We Fight films averaging between 40-80 minutes (just shy of feature length) and the American Scene documentaries averaging between 10-20 minutes (just over the standard length of the "shorts" that accompanied features, usually without being listed). 
published their own stories on the Jeep in the Netherlands, about its ingenuity and ubiquity, and about a population initially not knowing how to either pronounce or spell the name of the exciting new friend.

Toscanini-Hymn of the Nations, another episode of the American Scene series, was in a class by itself and had a remarkable circulation history in the Netherlands. At nearly thirty minutes, it was longer than the other American Scene documentaries and was mentioned in advertisements, be it in small print. The film recorded a now pivotal performance of Verdi's Hymn of the Nations with the legendary Arturo Toscanini conducting the NBC Symphony Orchestra. Toscanini was a beloved conductor in the Netherlands and around the world, notable for having left Fascist Italy for America and for refusing to play the Fascist anthem even before Mussolini officially took over. The movie thus paid tribute to America as a safe haven as well as to the political power of music. The film received rave reviews, and Toscanini's work was frequently programmed on the radio. KIJK also carried a story on Toscanini. Toscanini was without doubt the most frequently shown The American Scene documentary, not only in cinemas but, interestingly, also on the cultural Sunday mornings regularly organized by the communist newspaper De Waarheid, which embraced Toscanini's and Italian partisans' message of anti-fascism. Arturo Toscanini had added to Verdi's Hymn of the Nations, which included among others the British national anthem, not only America's Star Spangled Banner, but also The Internationale, in this way honoring the Soviet Union, and Italian partisans, in accordance with owI's guidelines and with Toscanini's political stand. De Waarheid often programmed the Toscanini film together with "The Battle of Russia" of the Why We Fight series and Nine Hundred, a film about Yugoslav partisans, together with live organ music and community singing. Before the war, Dutch censors had banned films that included The Internationale.

During the Cold War, De Waarheid frequently had Toscanini on its program, even though one of the essential messages of the film was that America provided a safe haven for opponents of oppressive regimes. Toscanini was also part of America's Cold War cultural diplomacy in the Netherlands, shown at the American Embassy, at hospital parties, and at union meetings. By that time, however, The Internationale had been cut out (Marvin 2014; Scott 2006a).

\section{In Conclusion}

This essay has sketched the general contours, goals and means of the owI Overseas Branch's elaborate "the Projection of America" propaganda campaign, and underscored the importance and impact of local circumstances on 
its deployment, in this instance in the Netherlands. The AIS/SHAEF exercised interregnum in each of the liberated countries until national governments were re-installed. In Belgium, for instance, although the struggle for liberation began on September 4, 1944 and was completed early in 1945, the Belgian government was already re-installed days after the battles began, on September 8, 1944; in France, in an explicit endeavor to avoid Allied military administration, the Republic was re-established even before D-Day. By contrast, the liberation of the Netherlands took longer than anticipated, from September 1944 until May 1945, and the Dutch government was finally installed in The Hague only in June 1945. The owI has been active in the Netherlands until December 1945, working together with the American Embassy in The Hague. The situation in the Netherlands was thus unique among the liberated countries in Western Europe, with SHAEF in charge a much longer time than elsewhere. It provided the OWI - and the MOI - unique opportunities for its propaganda operations.

"The Projection of America" was an impressive, large-scale, fine-grained, multi-media propaganda campaign that crossed social segments (elites and general public), and "bombarded" its audiences with different propaganda "weapons" from factual information (newsreels, KIJK, booklets), to subtle and personalized life stories (The American Scene documentaries), to confrontationally direct documentaries (Why We Fight series), to entertaining family movies (Hollywood films). In the aggregate, the campaign portrayed America as a nation of hardworking immigrants, dedicated to their families and communities, enjoying an enviably high standard of living, willing to risk their lives to defend democracy at home and abroad. The country was run by a government dedicated to not only win the war, but to secure international cooperation and peace afterwards as well.

The campaign's magazines, books and films all found a hearty welcome in the Netherlands. People lined up to get a copy of KIJK or to get into the cinemas. There was, however, discontent about the monopoly of American and British films, especially within the Dutch film industry, but also within the Dutch government. Yet, reality on the ground defined the terms of engagement between SHAEF/OWI and the Dutch in this respect.

What was the rationale behind this elaborate propaganda program? In the short run, the owI hoped to prevent frictions between American soldiers and Dutch civilians by mutually informing them about one another. But the agenda was much more expansive than that, and included several other motives. The American government anticipated taking up its role as the new leader of the free world.

This approach differed greatly from the isolationist turn it took in the international arena after the First World War. Success in this new position 
would turn on making sure that the "new followers" had a more balanced and informed assessment of what America stood for as a society than before the war, and trust in America's postwar foreign policy. "The Projection of America" was thus not an end in itself, but rather an instrument of foreign policy, even though the idealistic and liberal owi Overseas staff sometimes tended to overlook that (Wilson 2000, 84-85).

Another part of the owI Overseas Branch agenda was helping American business to protect and expand its markets, even though that was at odds with the official messages of the propaganda campaign. The long SHAEF interregnum in the Netherlands enabled the owI Overseas Branch to fulfill its promise towards the movie industry: securing the industry's holdings left behind after the German invasion, and providing Hollywood—and the British film industry - with unchallenged access to Dutch cinemas and the considerable revenues they represented. The owI was also able to support American publishing houses' efforts to expand their business in the Netherlands. By exhibiting the "American Way of Life" in all of its aspects through soldiers, publications, movies, and advertisements, the owI primed Dutch consumers for American products and the economic system behind them. In the postwar years, ongoing cultural diplomacy efforts and the Marshall Plan would reinforce these messages. The greater part of the Dutch population embraced the American products that came their way, and did so enthusiastically, while others were more wary about the prospect of Americanization.

In retrospect, we can see one other result of, if not motive, for these propaganda efforts. In the Dutch collective memory, America's role in the liberation narrative looms large. Yet, as important as it was, the role played by the British and Canadian military was of even more importance, and we see this reflected in the sad numbers of casualties. ${ }^{12}$ As Culbert and Chambers argue: "To an increasing degree, memory of wars won and lost, like other public memories, is a social construct" (Cit., Scott 20o8, 245). One can only speculate about the impact of "the Projection of America" program, with the Why We Fight series, and the period's Hollywood war movies such as The Sullivans and Action in the North Atlantic, along with those that would follow, such as Saving Private Ryan. But at all times, American soldiers were shown in the thick of the action. The massive and impressive American military cemetery

12 Numbers provided by the NIOD in Amsterdam: 6.700 British, 4.10o Canadian, 1.135 American and 630 Polish soldiers died in the Netherlands during the Second World War. Many casualties were repatriated, thus not buried in the Netherlands. 
of Margraten may have contributed to this narrative as well. While Canadian and British soldiers' bodies were buried in cemeteries spread across the Netherlands, American casualties were buried in one place, in Margraten, together with many American soldiers who died in Germany, on enemy soil (Kirkels and Purnot 2010). ${ }^{13}$ Americans have always keenly understood the cultural diplomacy aspects of cemeteries (and embassy buildings for that matter). Ron Robin cites those who identify American military cemeteries in Western Europe as a "forceful presence" and a political "foothold," as "symbols of America" (Robin 55). Over the years, the importance of Margraten as a site of commemoration of American sacrifices and of Dutch-American relations has only grown, acknowledged by high-level visitors such as Queen Beatrix and President G. W. Bush on Memorial Day in 2015. Perhaps even more telling is the fact that Dutch citizens have adopted all of the individual soldiers' graves. The recently collected personal stories of these soldiers give a face to America's sacrifice, something the owi Overseas Branch already tried to do in a more general way with the publication Schetsen van een Amerikaansch Familie Leven.

The implementation and reception of "the Projection of America" propaganda in the Netherlands is a topic that seems to have fallen between the cracks in studies of postwar cultural diplomacy and research on the Second World War, with its more familiar emphasis on the Occupation, the Holocaust, resistance and military battles. It deserves more attention, crucial as it is to both research agendas. It was part of the invasion and the liberation, but it was also the prototype for America's postwar cultural diplomacy efforts. Additional research on the 'receiving end' of "the Projection of America" campaign, in other countries, may yield more insights in the importance and impact of local circumstances.

\section{Bibliography}

Barnouw, Erik. 1993. Documentary: A History of Non-fiction Film. New York/Oxford: Oxford University Press.

Bennett, M. Todd. 2001. "Reel Relations: Cinema, Diplomacy, and the Grand Alliance, 1939 -1946." PhD diss., University of Georgia. ProQuest (AAT: 302541).

Bishop, Robert Lee. 1966. "The Overseas Branch of the Office of War Information." PhD diss., University of Wisconsin. ProQuest (Aat: 6613767).

13 See for more information on the history of this cemetery and the personal stories of the soldiers buried there the website http://www.margratenmemorial.nl 
Doherty, Thomas. 1993. Projections of War: Hollywood, American Culture, and World War II. New York: Columbia University Press.

Ellwood, David. 2012a. The Shock of America. Europe and the Challenge of the Century. Oxford: Oxford University Press.

Ellwood, David W. 2012 b. "The American Challenge in uniform: the Arrival of America's armies in World War II and European Women." European Journal of American Studies [Online], 7, no. 2 (2012), document 8. URL: http://ejas.revues .org/9577.

Haan, Jitze de. 199o. "Filmvoorziening in Nederland, 1945-1950." In Kunst en Beleid in Nederland, deel 4. Amsterdam: Boekmanstichting/Van Gennep, 57-95.

Hart, Justin. 2013. Empire of Ideas. The Origins of Public Diplomacy and the Transformation of U.S. Foreign Policy. Oxford: Oxford University Press.

Hench, John B. 201 o. Books as Weapons. Propaganda, Publishing, and the Battle for Global Markets in the Era of World War II. Ithaca/London: Cornell University Press. Kirkels Mieke, and Jo Putnot. 2010. From Farmland to Soldiers Cemetery. Eyewitness Accounts of the Construction of the American Cemetery in Margraten. Den Bosch: Heinen Uitgeverij.

Klinkert, Wim. 2009. "Crossing Borders: Americans and the liberation of the Netherlands." In Four Centuries of Dutch-American Relations: 16o9-20og, edited by Hans Krabbendam, Cornelis A. van Minnen and Giles Scott-Smith, 565-76. Amsterdam: Boom.

Koppes, Clayton R., and Gregory D. Black. 1977. "What to Show to the World: The Office of War Information and Hollywood, 1942-1945." The Journal of American History, 64, no. 1: 87-105.

Laurie, C.D. 1996. The Propaganda Warriors: America's Crusade against Nazi Germany. Lawrence: University of Kansas.

MacCann, Richard Dyer. 1973. The People's Film: A Political History of U.S. Government Motion Pictures. New York: Hasting House Publishers.

Marvin, Roberta Montemorra. 2014. The Politics of Verdi's Cantica. Burlington, VT: Ashgate Publishing Company.

Oudheusden, J.A. van, and H. Termeer. 1994. Tussen Vrijheid en Vrede. Het Bevrijde Zuiden, September '44-mei' 45. Zwolle: Waanders.

Robin, Ron. 1995. “'A Foothold in Europe': The Aesthetics and Politics of American War Cemeteries in Western Europe." Journal of American Studies 29, no.1 (April 1995): 55-72.

Roholl, Marja. 1994. "A Catholic Wonderland: Pictorial Images of America in Katholieke Ilustratie, 1867-1942." In American Photographs in Europe, edited by David E. Nye and Mick Gidley, 130-57. Amsterdam: vu University Press.

Roholl, M. 1996. “'A Full and Fair Picture': American Foreign Cultural Policy vis-àvis the Netherlands, 1945-196o." In American Culture in the Netherlands, edited 
by Doeko Bosscher, Marja Roholl, and Mel van Elteren, 165-95. Amsterdam: vU University Press.

Roholl, Marja. 2012. "Preparing for Victory. The U.s. Office of War Information Overseas Branch's Illustrated Magazines in the Netherlands and the Foundations for the American Century, 1944-1945." European Journal of American Studies [Online], 7, no. 2 (2012), document 10. URL: http://ejas.revues.org/9577.

Rosenberg, Emily S. 1999. "Consuming Women: Images of Americanization in the 'American Century,"' Diplomatic History 23, no. 3 (Summer 1999): 479-97.

Schrijvers, Peter. 2009. Liberators: The Allies and Belgian Society, 1944-1945. Cambridge, UK: Cambridge University Press.

Schrijvers, Peter. 2012. “'A Modern Liberation': Belgium and the Start of the American Century, 1944-1946." European Journal of American Studies [Online], 7, no. 2 (2012), document 9. URL: http://ejas.revues.org/9577.

Schoonoord, D.C.L. 2010. “'Het 'Circus Kruls'. Militair Gezag in Nederland, 1944-1946.” Militaire Spectator, 179, no. 5:265-76.

Scott, Ian. 2006a. "From Toscanini to Tennessee: Robert Riskin, the OWI and the Construction of American Propaganda in World War II." Journal of American Studies, 40, no. 2 (August 2006): 347-66.

Scott, Ian. 20o6b. In Capra's Shadow: The Life and Career of Screenwriter Robert Riskin. Lexington, KY: University Press of Kentucky.

Scott, Ian. 2008. "Why We Fight and Projections of America. Frank Capra, Robert Riskin, and the Making of World War II Propaganda." In Why We Fought: America's Wars in Film and History, edited by Peter C. Rollins, and John E. O'Connor, 242-58. Lexington, KY: University Press of Kentucky.

Segrave, Kerry. 1995. American Films Abroad: Hollywood's Domination of the World's Movie Screen from the 1890 os to the Present. Jefferson, NC: McFarland.

Winkler, Alan. 1978. The Politics of Propaganda. The Office of War Information, 1942-1 945. New Haven/London: Yale University Press.

Wilson, Theodore A. 2000. "Selling America via de Silver Screen. Efforts to Manage the Projection of American Culture Abroad." In 'Here, There and Everywhere.' The Foreign Politics of American Popular Culture, edited by Reinhold Wagnleitner and Elaine Tyler May, 83-100. Hanover, NE/London: University Press of New England.

\section{Primary Sources}

Allen, Mildred E. 1945, March 13. Long Range Operational Plan for Holland, 7. NARA, RG 208-OWI. Records of the Historian. Area files: 1943-1945, box 2: file Holland. American Jewish Outlook, The. 1944. June 9. 
Anonymus. 1943. "OWI Films to Tell World How U.S. Folk Behave. Plans Factual Subjects to 'Dispel Fanciful' Ideas about This Country." Motion Picture Herald, March 13.

Anonymus. 1943. U.s. "Products to Follow Invading Allied Armies." Motion Picture Herald, August 7 .

Cousins, Norman. 1944. Alice Curran's Review Board Memorandum, December 5, 1944. Charles M. Hulten Papers, Box 5. Harry S. Truman Library, Independence, Missouri. Department of State, U.S.A. 1944. Vrede en Oorlog. 1944. De Buitenlandsche Politiek der Vereenigde Staten van Amerika in de Jaren 1931-1941. New York: Transatlantic.

Hulten, Charles M. Papers. 1943-1946. Office of War Information, box 1-8. Harry S. Truman Library, Independence Missouri.

Huxley, Julian. 1944 De Wonder-Vallei. "T.V.A..” De Lotgevallen van een Ontwerps Organisatie. New York: Transatlantic.

Jarvie, Ian. 1990. "The Postwar Economic Foreign Policy of the American Film Industry. Europe 1945-1950." Film History 4: 277-288.

Miller, Peter. 2014. Projections of America (Germany: Hollywood an die Front), ARTE TV, 23 September 2014. A Film directed by Peter Miller, produced by DocDAYS Productions and Willow Pond Film. Distributed by PBs International.

Pryor, Thomas M. 1943. "Dispelling a Harmful Illusion.” New York Times, March 7.

PWD/SHAEF. 1951. The Psychological Warfare Division, Supreme Headquarters Allied Expeditionary Force. An Account of its operations in the Western European Campaign, 1944-1945 [s.l.].

Schreven, M. Van. 1944. To Mrs. Alice Curran, Review Board, ов, Projection of America, December 6. Charles M. Hulten Papers, box 5: folder: Holland. Harry S. Truman Library, Independence Missouri.

U.S. O.W.I. [1945]. OWI in the ETO, a Report on the Activities of the Office of War Information in the European Theatre of Operations, January 1944-January 1945. [London].

Wilson, Dave. November 30, 1944. To Washington Review Board. Attached Draft Outline of a Directive on Projection of America. OWI: OwI folder, Box 7, Charles M. Hulten Papers. Harry S. Truman Library, Independence, Missouri. 